\title{
A HARCTÉRI SEBESÜLÉS-ELLÁTÁSI SZIMULÁTOR
}

\author{
THE TACTICAL CASUALTY CARE SIMULATOR
}

\author{
VIRÁGH Krisztián \\ (ORCID: 0000-0003-4184-9492) \\ viragh.krisztian97@gmail.com
}

\begin{abstract}
Absztrakt
A Zrínyi 2026 Honvédelmi és Haderöfejlesztési Program egy nagyszabású modernizációs terv a Magyar Honvédség fejlesztése, hatékonyságának növelése érdekében. Az ehhez szükséges korszerü technikai eszközpark beszerzésének anyagi fedezete a döntéshozók szándéka szerint biztositásra kerül.

A kiképzés területén használható szimulációs rendszerek lehetöséget biztositanak a katonák felkészítése során realisztikus körülmények megteremtésére, ami segíti a valós helyzetekben való tevékenységek hatékony begyakorlását, így integrálásuk a felkészités rendszerébe indokolt.

A katonák életének müvelti területen való megóvása érdekében a korszerü haderőkben az egészségügyi felkészités a kiképzés során egyre nagyobb szerephez jut, melyet eredményesen támogathatnak olyan harctéri sebesülés-ellátó szimulátor rendszerek, melyek a különböző szintü sérülések kezeléséhez, különböző realisztikus tanbábú készleteket tartalmaznak.
\end{abstract}

Kulcsszavak: kiképzési rendszer, sebesülésellátás, szimulátor

\begin{abstract}
The Zrínyi 2026 National Defence and Armed Forces Development Program is a large-scale modernization plan for the development of the Hungarian Defence Forces. The government decides about the purchase of the required technical pieces

During the soldiers' training different simulators give opportunity to increase efficiency of the training by providing realistic circumstances so the integration of these simulators into the training system is necessary.

In order to protect the lives of soldiers in the field of operation, medical training in the modern forces is gaining more and more importance, which can be successfully supported by casualty care simulators.
\end{abstract}

Keywords: training system, casualty care, simulator 


\section{BEVEZETÉS}

A Zrínyi 2026 Honvédelmi és Haderőfejlesztési Program egy nagyszabású modernizációs terv, amelynek célja a Magyar Honvédség fejlesztése, hatékonyságának növelése. Az ehhez szükséges korszerü technikai eszközpark beszerzésének anyagi fedezete a döntéshozók szándéka szerint biztosításra kerül. Ennek következtében az elkövetkezendő 8-10 évben nagy átalakulásokon fog keresztülmenni a magyar katonaság.

Néhány elemét már ismerhetjük, ilyen például a helikopterképesség növelése a H145M típusú helikopterek katonai változatának beszerzésével, az új 2015M hadi-gyakorlóegyenruha rendszeresítése, vagy a többszáz Suzuki Vitara szolgálati gépjármü átadása. A programról érthető okok miatt nem tesznek közzé több információt, mint szükséges. Megjelent azonban egy brossúra, amelyben nagy vonalakban leírják azokat az irányelveket és esetenként konkrét elemeket, amelyeket változtatni kívánnak. Ebben írtak a Magyar Honvédség egészségügyi ellátásáról is. Olyan információkat tették közzé, miszerint egy tábori kórház létesítéséhez szükséges eszközöket készülnek beszerezni. Úgy gondolom, hogy ezen törekvések megvalósulása mindenképpen a honvédség képességfejlődését fogja eredményezni, ugyanakkor eddigi információink alapján a katonák egészségügyi képzésén nem terveznek lényegi változtatást végrehajtani. [1] [2] [3]

Aki már vett részt egészségügyi képzésekben, például jogosítvány szerzése miatt, vagy katonai alapkiképzés alatt, az megtapasztalhatta azt, hogy egyes helyzetekben az egyszerü tanbábuk alkalmazása túlságosan is „labor körülmények” között zajlik.

A különböző missziók esetében a katonák életének müvelti területen való megóvása egyre nagyobb szerephez jut. Véleményem szerint ennek hatékony kivitelezéséhez azonban nem elegendő a korábban említett „labor körülmények” biztosítása, a kiképzés realisztikusságát növelni kell a gyakorlások körülményeinek a valós helyzetekhez való közelítésével. Léteznek már olyan megoldások, amiket az életszerüség növelése érdekében hatékonyan fel tudnánk használni a jövőben, mint például különböző sebesülés-szimulátorok.

Kutatásom ideje alatt arra kerestem a választ, hogy melyik szimulátor alkalmas betölteni a korábban felvázolt szerepet. A választ a harctéri sebesülés-ellátási szimulátorban találtam meg, amely véleményem szerint megfelel a korszerü képzéssel szemben támasztott komplex követelményrendszernek, és így képes forradalmasítani az egészségügyi képzést.

\section{HARCTÉRI SEBESÜLÉS-ELLÁTÁSI SZIMULÁTOR}

\section{A szimulátor rövid története}

A harctéri sebesülés-ellátási szimulátor $\left(\mathrm{TCCS}^{1}\right)$ egy, az Operations Experience Inc. által kifejlesztett termékek közül. A vállalat alapvetően különböző egészségügyi problémákat, sérüléseket feldolgozó szervezet, amelynek célja, hogy forradalmasítsák a sebészek, az orvosok és az egészségügyi csapatok képzését nagyrészletességü anatómiai és sebészeti pontossággal kifejlesztett szimulátorok segítségével, így egy átfogó tapasztalatszerzési lehetőség kereteit megteremtve. Mindezt természetesen költséghatékony módon megtervezve. [4]

A vállalat alapjait Dr. Robert Buckman traumatológiai sebész kutatásai teremtették meg, aki korábban missziós környezetben is tevékenykedett orvosként. Többéves szolgálata során olyan átfogó tapasztalatra tett szert, amelyekre alapozva azt kezdte el vizsgálni, hogy a sebészeti oktatásban milyen anyagok alkalmasak az emberi szövetekhez hasonló hatás elérésére gyakorlás közben. Jeffrey Ellis-szel együttmüködve megalkották a világ első olyan

\footnotetext{
${ }^{1}$ Tactical Casualty Care Simulator: harctéri sebesülés-ellátási szimulátor
} 
szimulátorát, amelyen sebészeti beavatkozást lehetett végezni a hagyományos sebészeti eszközökkel, ezzel úttörővé válva a területen. Az egész kutatás megvalósításához, majd az Operations Experience megalapításához U.S. Army Medical Research and Materiel Command (USAMRMC) biztosította a szükséges tőkét. [4]

\section{A harctéri sebesülés-ellátási szimulátor rendeltetése}

A harctéri sebesülés-ellátási szimulátor egy olyan strapabíró, egész alakos tanbábukészlet, amit a harcitéri sebesülés-ellátás átfogó képzését teszi lehetővé különböző sebesülési mintákkal, traumatikus sérülésekkel, a robbanás által okozott sérülésektől egészen a lőtt sebekig. Célja, hogy felkészítse a katonákat hazai, illetve külhoni szolgálatok alkalmával jelentkező harctéri sérülések ellátására, ezzel növelve a túlélési esélyeket.

\section{A harctéri sebesülés-ellátási szimulátor fajtái}

A szimulátorhoz öt, egymástól elkülönülő tanbábu tartozik, amelyek más-más sérüléseket mutatnak be. Ezek mindegyike alkalmas a katonák egészségügyi képzésének a támogatására, mert széles körben teszik lehetővé a különböző sérülések ellátásának begyakorlását.

\section{Első sebesülési minta}

Az első sebesülési minta sérülései [5]:

- Lőtt seb az arc jobb oldalán, amely vérzéses fulladást okoz;

- Bal felkaron lévő lőtt sérülés;

- Repesz okozta sebesülés a mellkas jobb tájékán.

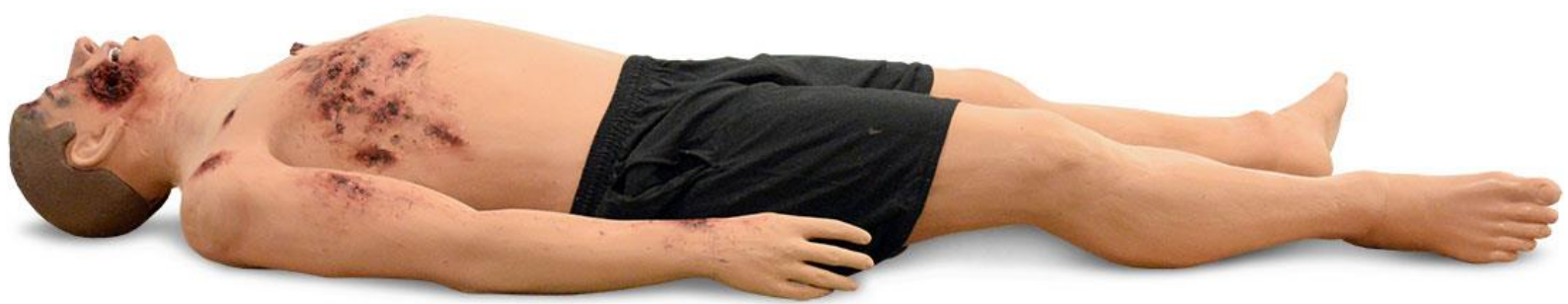

1. ábra: Első sebesülési minta [5]

\section{Második sebesülési minta}

A második sebesülési minta sérülései [6]:

- Repesz okozta sérülés a nyakon, amely súlyos vérzést okoz;

- Rézsútos, bemeneti és kimeneti nyílással rendelkező lőtt sérülés a jobb lágyékon (a tourniquet ${ }^{2}$ felhelyezésének vonala fölött);

- Lött sérülés a bal combon;

- Nyílt szárkapocscsont, valamint sípcsonttörés.

\footnotetext{
${ }^{2}$ Tourniquet: egyfajta érelszorító eszköz
} 


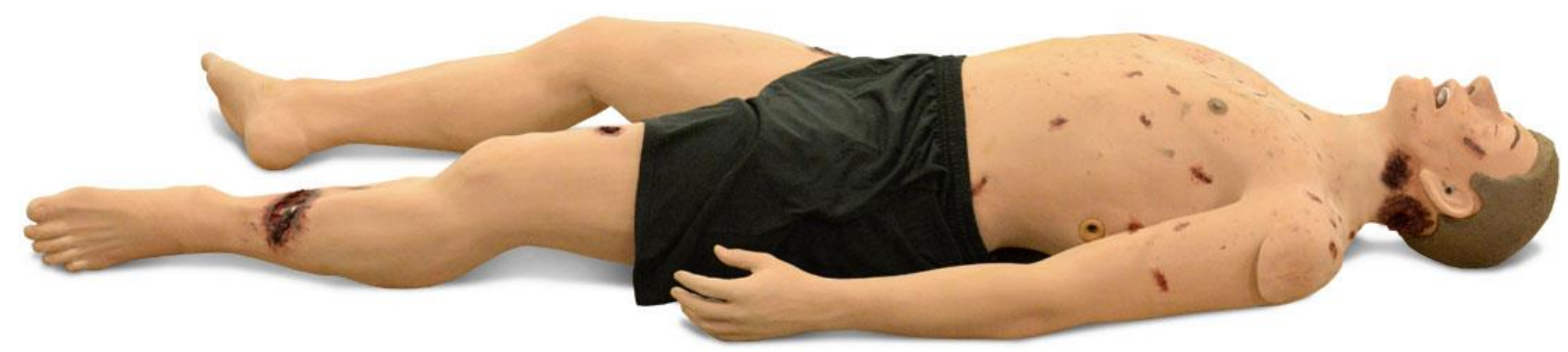

2. ábra: Második sebesülési minta [6]

\section{Harmadik sebesülési minta}

A harmadik sebesülési minta sérülései [7]:

- Traumás amputációk:

○ bal könyöktöl;

○ bal térdtől;

○ jobb comb felső részétől (a tourniquet felhelyezésének vonala fölött);

- Égés, robbanás okozta és/vagy repesz okozta sérülés a test bal oldalán.

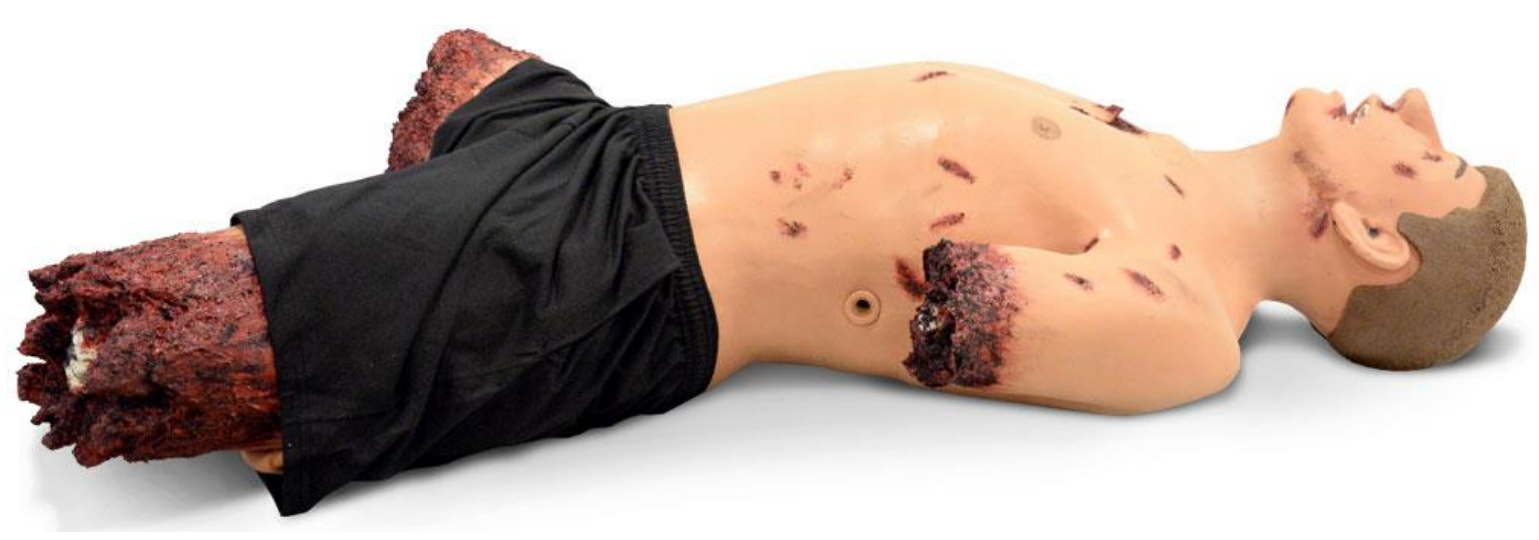

3. ábra: Harmadik sebesülési minta [7]

\section{Negyedik sebesülési minta}

A negyedik sebesülési minta sérülései [8]:

- Traumás amputációk:
○ bal könyöktöl;

○ bal térdtöl;

- Légmell;

- Égések az arc bal oldalán;

- Repesz okozta sérülések a test bal oldalán.

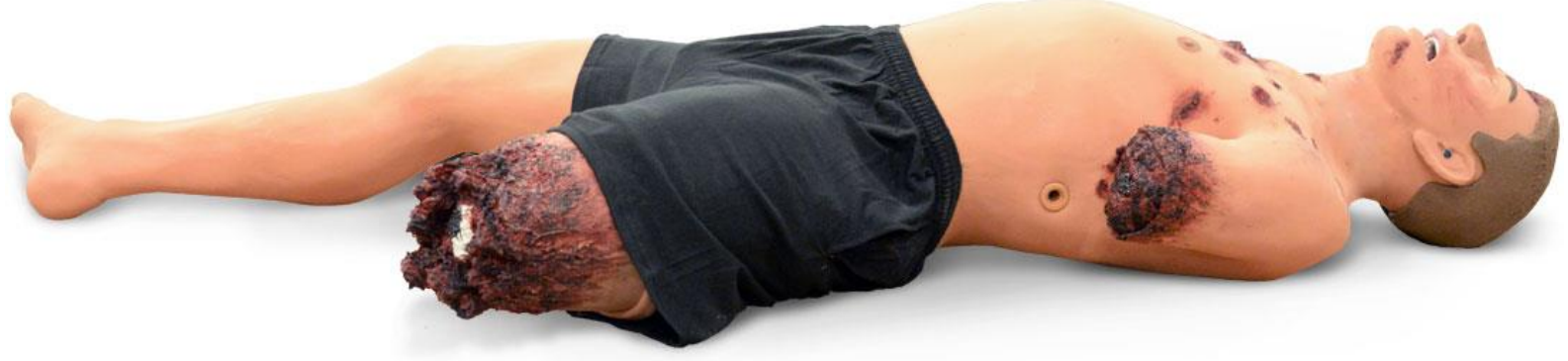

4. ábra: Negyedik sebesülési minta [8] 


\section{Ötödik sebesülési minta}

Az ötödik sebesülési minta sérülései [9]:

- Nyílt hasi sérülés (szervek hason kívül);

- Traumás amputáció a jobb csuklótól;

- Mély sérülés a jobb combon hátsó/oldalsó részén.

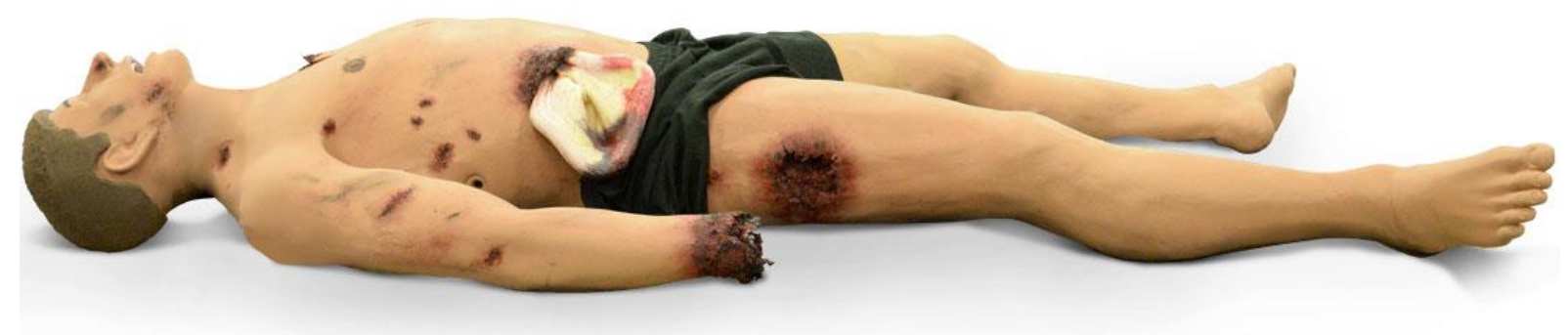

5. ábra: Ötödik sebesülési minta [9]

\section{A harctéri sebesülés-ellátási szimulátor jellemzői}

A szimulátor arra lett tervezve, hogy biztosítsa az ellátó állomány részére azt a képzést, amely lehetővé teszi a kórházi ellátás előtti időszak tevékenységeinek, mint a sebesüléskezelésnek, a légút-biztosításnak és a vérzéscsillapításnak gyakorlását élethü szövetek és nagy anatómiai részletességgel kidolgozott testrészek segítségével.

Az egész alakos szimulátor a valóságnak megfelelö méretü és tömegü, valamint teljes részletességgel kidolgozott végtagokkal rendelkezik. Alkalmas a fokozottan veszélyes környezetben való tevékenykedés begyakorlására. A tanbábuk fö paraméterei: méret $192 \mathrm{~cm} \mathrm{x}$ $70 \mathrm{~cm}$ x $30 \mathrm{~cm}$, tömeg $84 \mathrm{~kg}$, ami egy felnőtt férfi testfelépítésének feleltethető meg. Az, hogy készül-e később női változatban is tanbábu még nyitott kérdés. A minél realisztikusabb megjelenítés érdekében 113,5 liter koncentrált, mikroba- és gombaellenes, fagyálló müvér jár a készlethez. [10]

A rendszert könnyü irányítani, ugyanis felhasználóbarát felülete a modern kor technikai viszonyaihoz igazodva iOS vagy Android operációs rendszerrel futó táblagéppel távvezérelhető. Ez a távvezérlés sík terepen, zavaró tényezők nélkül egészen 91 méteres távolságban is müködik. A szimulátor teljes mértékben mobilis, vízálló, beltérben és kültéren az időjárási viszonyoktól, és a terep átszegdeltségétől függetlenül használható. A tanbábuk szállítására strapabíró hordtáskát biztosítanak. [10] [11]

A távvezérléssel befolyásolni lehet a légzésszámot és szívfrekvenciát, a vérzés ritmikusságát, pulzálását. Nemcsak a távvezérlésre, hanem a kétirányú, folyamatos, „headset” kommunikációra is van lehetőség, így az ellátó és az irányító közöti információáramlás biztosított, ami még hatékonyabb ellátást eredményezhet. A szimulátor csaknem 2 napon keresztül képes üzemelni, valamivel több, mint 45 órán keresztül. Ezt a dupla lítiumion akkumulátor teszi lehetővé. [10] [11] 


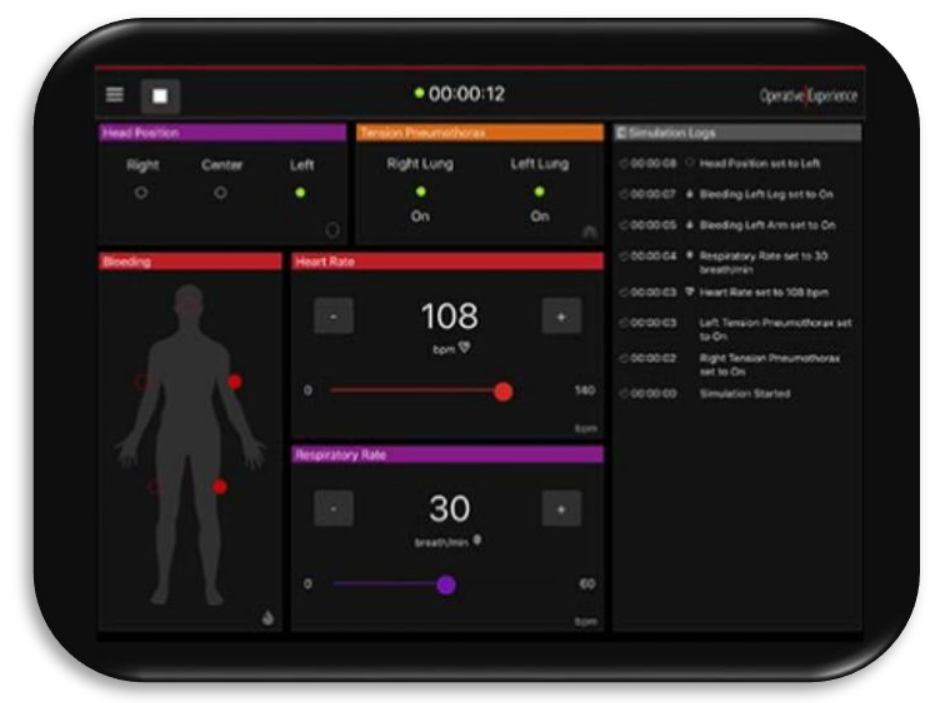

6. ábra: A szimulátor kezelőfelülete [12]

A szimulátor alkalmas mindhárom vérzéstípus (hajszáleres, vénás, artériás) szimulálására, és a korábban bemutatott sebesülési mintákkal a többek között a következő ellátói feladatokat lehet begyakorolni segítségével [5] [6] [7] [8] [9]:

- sebkötözés;

- lött sérülések ellátása;

- légútbiztosítás (idegen test a légutakban, gégemetszés);

- amputált felső- és alsóvégtagok ellátása;

- robbanás okozta sérülések, repeszek által okozott sérülések ellátása;

- többfokú égési sérülések kezelése;

- a felkarcsonti és szegycsonti intraosszeális infúzió bekötése;

- tüvel végzett dekompresszió a légmell tüneteinek a kezelésének érdekében;

- nyílt törések ellátása.

Látható, hogy a tanbábuk a legtöbb harci körülmény között elszenvedett sérülést képesek imitálni. Ha a korábban bemutatott jellemzőket, tulajdonságokat összehangoljuk, akkor komplex helyzeteket, forgatókönyveket tudunk létrehozni a kiképzendő állomány részére. Kiemelendő az a tény, hogy ha helytelen ellátásban részesül a sérült, akkor a távvezérlés segítségével a légzési és szívritmus gyorsítható/lassítható, a vérzés lüktetése fokozható, így élethübb reakciókat kiváltva a sérült részéről.

\section{A harctéri sebesülés-ellátási szimulátor felhasználási lehetőségei}

Mivel a tanbábu ilyen sokféle sebesülés szimulálására képes, felhasználhatósága rendkívül kiterjedt. Elsősorban katonai szempontból vizsgálva tökéletesen alkalmas a Müveleti Első Ellátó Katonák ${ }^{3}$ képzésére, a Harctéri Életmentés $\left(\mathrm{CLS}^{4}\right)$ oktatására, valamint az alapkiképzés során tartott egészségügyi foglalkozások során való alkalmazásra.

\footnotetext{
${ }^{3}$ First Responder

${ }^{4}$ Combat Life Saving
} 


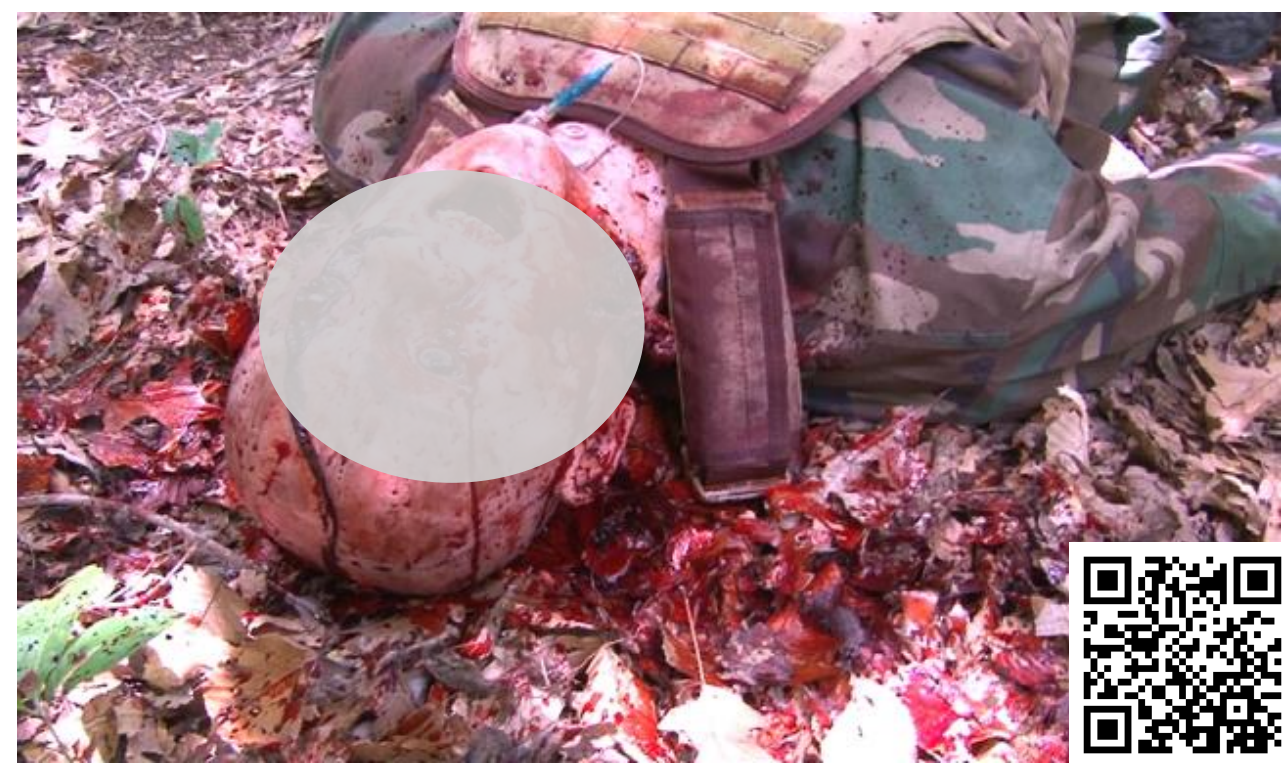

7. ábra: A szimulátor használata harctéri körülmények között [13] [14]

Másodsorban egyéb szervezetek is ugyanúgy használni tudják a szimulátort, például a rendörök, akik egyes esetekben hasonló veszélynek vannak kitéve, mint a katonák, hiszen a terrorizmus terjedése miatt egy IED $^{5}$ robbanása például egy forgalmas városrészben hasonló sérüléseket okozhat. E forgatókönyv esetében áldozatok, sebesültek is lesznek, és a helyzettől függően a rendőr is elsősegély ellátást nyújthat.

Azonban nem kell feltétlenül egyből terrorizmusra gondolni, mert a bünözés különböző formái bárhol előfordulhatnak, és ezek sokszor járnak fizikai sérülésekkel, így a megfelelő felkészültség egészségügyi ellátás terén semmiféleképpen sem elhanyagolható a rendőrök esetében sem.

Ugyanez a helyzet a katasztrófavédelem kötelékében szolgáló tüzoltókkal, akik munkaköre békeidőszakban is kiemelten veszélyes. A tüzesetek, természeti és ipari katasztrófák, müszaki mentések alkalmával sokszor kell megbirkózni az égési serülések, légzési nehézségek, törések, egyéb fizikai sérülések ellátásával. A tanbábuk sebesülési mintái ezek ellátásra sikeresen fel tudnák őket készíteni, így növelve a sérültek túlélési esélyeit.

A mentőszolgálatok dolgozói természetesen bármelyik sebesülési mintával nagyobb valószínüséggel találkozhatnak. Részükre úgy vélem elengedhetetlen lenne az, hogy a következő generációs tanbábukon gyakorolhassanak. Általános elsősegélytanfolyamok ideje alatt is lehetne használni a tanbábukat.

Ha ilyen foglalkozásokon realisztikusan megjelenő bábukon gyakorolhatnak a résztvevők, kevesebb olyan eset fordulhatna elő, hogy bár az adott személy részesült elsősegély oktatásban, de a sérülés látványa miatt a gyakorlatban nem képes annak ellátására.

\footnotetext{
${ }^{5}$ Improvised Explosive Devices - Rögtönzött Robbanó Eszközök
} 


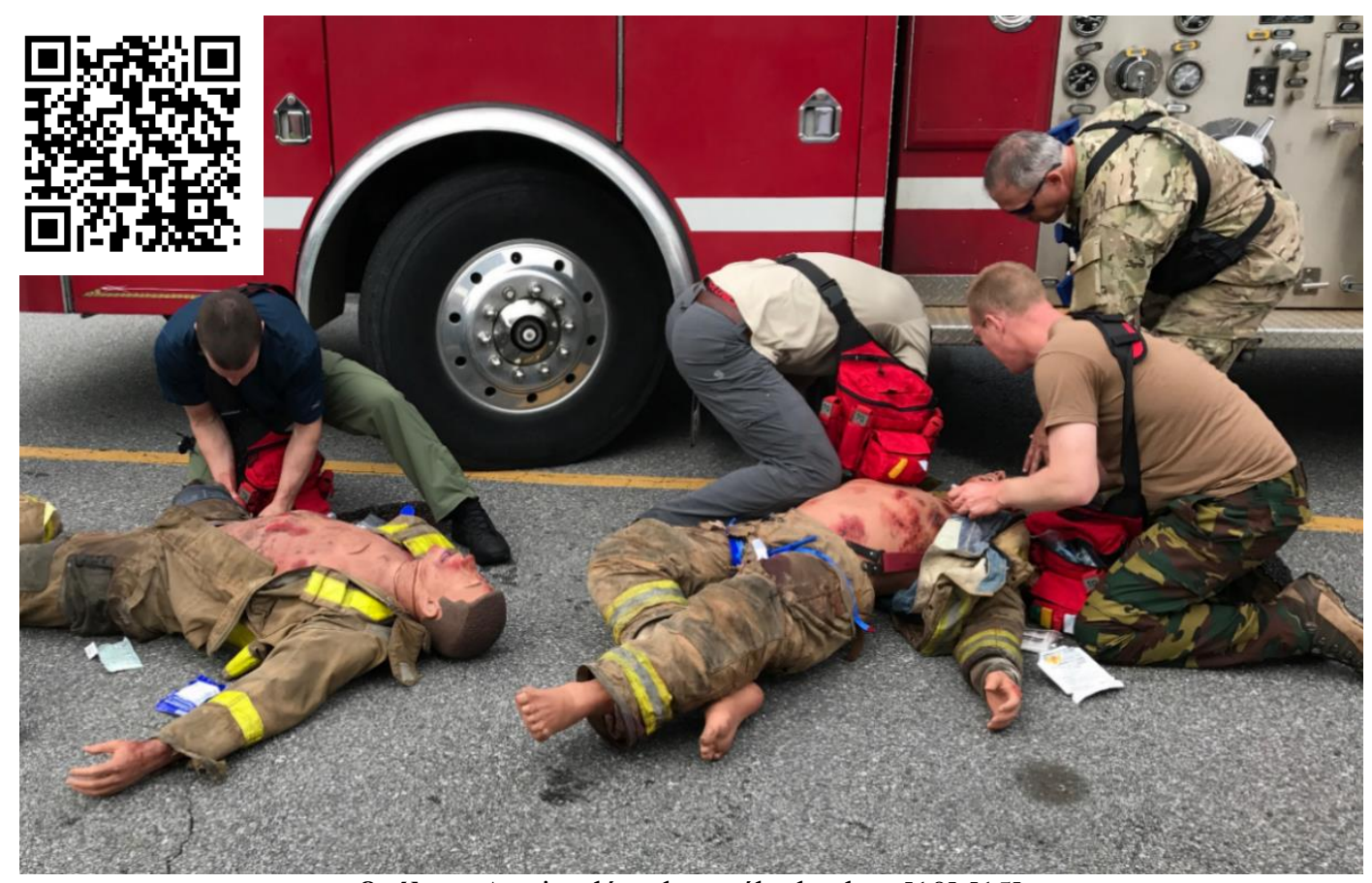

8. ábra: A szimulátor használat közben [10] [15]

A szimulátor esetében a sokkoló látványt nyújtó sérülések okozta trauma nem lenne ismeretlen az ellátok számára, így a valós szituációban nem lenne cselekvőképtelen, nem is beszélve arról, hogy akár a közvetlen életveszélyt jelentő sérülések kezelésére is képessé válhatnának segítségükkel.

\section{ÖSSZEGZÉS}

Kutatásom során áttekintettem a harctéri sebesülés-ellátási szimulátor rövid történetét, rendeltetését, fajtáit, jellemzőit, felhasználhatósági lehetőségeit, és a megfelelő konzekvenciákat levonva javaslatot tettem a szimulátor beszerzésére és integrálására a Magyar Honvédség és más szolgálatok egészségügyi képzési rendszerébe.

Úgy gondolom, hogy a szimulátor alkalmazása nagy előnyt jelentene nemcsak a hazai képzésben, hanem még a külhoni szolgálat és nemzetközi keretek között zajló müveletek, missziók esetében is, így indokoltnak tekinthető beillesztésük a rendszerbe.

Szükségessé vált, hogy megvizsgáljuk a Magyar Honvédség új szervezeti struktúrájában, milyen egészségügyi biztosítási, kiképzési és felkészítési igények merülhetnek fel. Egy korszerü haderő kialakítása során meg kell, hogy változzon a katonákkal szemben támasztott követelményrendszer, azaz többek között az elvárt készségek és képességek formája és szintje. Az új elvárásokhoz természetesen újra kell gondolni a kiképzés rendszerét, és szükség esetén az alapkiképzésre épülő egy-egy képességet előtérbe helyező modulrendszerü felkészítésre kell törekedni. Két kérdés vetődik fel ezzel kapcsolatban. Az első, hogy az elsősegélynyújtási, illetve különböző szintü egészségügyi szakszemélyzeti, illetve ellátási modulok ismeretanyagának elsajátítása, illetve begyakorlása során mennyivel javítja a hatékonyságot és gyorsítja a kiképzést a harctéri sebesülés-ellátási szimulátor alkalmazása. A második, hogy ezek alapján melyek legyenek azok a szintek, ahol használatuk akár elengedhetetlenül szükséges lesz a jövőben. Ezt követően lehet megfogalmazni a konkrét igényeket, felkészülni a csapatpróbák végrehajtására, feldolgozni a tapasztalatokat és beválás esetén tervezni a rendszerbeállítás, illetve ellátás ütemezését, kialakítani a logisztikai kiszolgálás rendszerét. 
Eddigi ismereteim alapján ki tudom jelenteni, hogy a szimulátorok megfelelnek a korszerü egészségügyi kiképzéssel és felkészítéssel szemben támasztott követelményeknek, alkalmazásuk nagyban növelné kiképzési foglalkozások hatékonyságát.

Meglátásom szerint már az alapkiképzés szintjén is használni kellene ezeket az eszközöket, ezzel csökkentve a harctéri sokk kialakulásának esélyeit. További lehetőségek vannak a Műveleti Első Ellátó katonák képzésben, a Harctéri Életmentés oktatásában, illetőleg a különböző csapatgyakorlatok lebonyolítása során.

Az eszköz beszerzését megelőző kísérleti szakaszban kezdetben csupán néhány készlet tanbábu beszerzése lenne indokolt mind az 5 sebesülési mintával, melyeket a tiszt- és tiszthelyettes képző tanintézetekben, illetve az egészségügyi szakkiképzést folytató alegységeknél lehetne csapatpróbáztatni. Javaslatom illeszkedik a Zrínyi 2026 program célkitüzéseihez, ezért a szükséges forrásokat ennek keretében kellene biztosítani.

\section{FELHASZNÁLT IRODALOM}

[1] https://honvedelem.hu/cikk/111144_folytatodik_a_hadero_fejlesztese_uj_katonai_helik optereket_szerez_be_a_honvedseg (Letöltve: 2018.11.07.)

[2] https://www.honvedelem.hu/cikk/61339_zrinyi_2026 (Letöltve: 2018.11.07.)

[3] https://honvedelem.hu/cikk/109984_folytatodik_a_magyar_honvedseg_fejlesztese (Letöltve: 2018.11.07.)

[4] https://operativeexperience.com/about/ (Letöltve: 2018.11.13.)

[5] https://operativeexperience.com/tactical-casualty-care-simulator-1-2/ (Letöltve: 2018.11.14.)

[6] https://operativeexperience.com/tactical-casualty-care-simulator-2/ (Letöltve: 2018.11.14.)

[7] https://operativeexperience.com/tactical-casualty-care-simulator-3/ (Letöltve: 2018.11.14.)

[8] https://operativeexperience.com/tactical-casualty-care-simulator-4/ (Letöltve: 2018.11.14.)

[9] https://operativeexperience.com/tactical-casualty-care-simulator-5/ (Letöltve: 2018.11.14.)

[10] https://operativeexperience.com/tactical-hemorrhage-control-trainer/ (Letöltve: 2018.11.15.)

[11] https://operativeexperience.com/wp-content/uploads/2018/04/OEI-TCCSSellSheet_LRFINAL.pdf (Letöltve: 2018.11.15.)

[12] https://operativeexperience.com/wp-content/uploads/2018/07/tccs1-instructor-tablet.jpg (Letöltve: 2018.11.15.)

[13] https://operativeexperience.com/wpcontent/uploads/2016/11/tactical_casualty_care_simulator_gsw.jpg (Letöltve: 2018.11.15.)

[14] https://www.youtube.com/watch?v=DhxUtoSR9WM QR-kódhoz tartozó videó hivatkozása, Letöltve: 2018.11.16.

[15] https://www.youtube.com/watch?time continue=48\&v=XFPcuFs YM7A QR-kódhoz tartozó videó hivatkozása, Letöltve: 2018.11.16. 